ogies offer a highly decentralised and flexible power source which, if widely used, would result in a very different world from one powered chiefly by large central generating stations running on coal or nuclear fission. Solar technologies, Hayes argues, "are more compatible than centralised technologies with social equity, freedom and cultural pluralism".

Hayes's basic message, therefore, is that a transition to a solar era "would be technically feasible, economically sound, and environmentally attractive". Furthermore, "the most intriguing aspect of a solar transition might lie in its social and political ramifications". A constant refrain running through Hayes's study is that many relatively unsophisticated solar technologies are already sufficiently developed to be put to use, either alone or in tandem.

On solar heating and cooling, for example, he argues that more attention should be paid to the thermodynamic efficiency of energy production and use, suggesting that it is "surely the height of thermodynamic foolishness" to use a nuclear reactor operating at thousands of degrees to run a water heater to heat bath water to 30 degrees. About a third of the energy now used in the world provides low-temperature heat, which solar collectors can already achieve in many parts of the world, Hayes claims. Moreover, if the lifetime fuels costs are properly counted in economic comparisons, he contends that solar heaters are already able to compete with conventional fuels.

Another promising renewable energy source is small hydroelectric plants which could easily be constructed to serve small villages. Even in the United States, Hayes reckons, there may be a as many as 50,000 potential sites available for hydropower plants as small as half a megawatt. There is also a large and relatively untapped source of energy from the production of methane from animal wastes, ethanol from fermenting plant wastes, and lowgrade heat from biomass, Hayes suggests. A start has, however, been made on some of those technologies, particularly in India and China which are operating a substantial number of methane plants, and Brazil and Australia, where fermentation plants running on sugar cane and eucalyptus wastes are already in production.

As for more sophisticated uses of solar energy, such as large-scale generation of electricity, Hayes argues that although massive solar generating plants would hold considerable environmental advantages over conventional and nuclear power stations, they would also carry some of the disadvantages of inefficiency and centralisation. "A

\title{
Recombinant DNA bill proposed
}

ThE Carter Administration last week finally proposed legislation to control all recombinant DNA experiments in the United States, after some three weeks of discussions between the Secretary of Health, Education and Welfare (HEW) and officials from the National Institutes of Health (NIH) and the White House. Although the final version of the bill conforms closely to a draft version proposed last month by an interagency task force, it differs in one key respect: it would allow state and local governments to establish controls on the research which are more stringent than the federal regulations.

The bill was formally introduced into the Senate last week by Senator Edward Kennedy, Chairman of the Senate Health Subcommittee which will handle the legislation. Kennedy made clear, however, that he doesn't necessarily agree with every word in the bill and in a statement he outlined a few reservations with the Administration's approach.

The bill would essentially require the Secretary of HEW to establish regulations to control recombinant DNA research in both public and private institutions. He would be required to issue interim regulations within 90 days and a final version within a year, after allowing suitable time for public comments and discussion. The interim regulations, at least, would probably be the guidelines issued last year by NIH. The bill would also require that all facilities housing recombinant DNA experiments be licensed by HEW.

There is also a provision in the bill which would empower $\mathrm{HEW}$ to

sensible energy strategy demands more than the simple-minded substitution of sunlight for uranium," he suggests. Photovoltaic cells, which convert sunlight directly to electricity, have the advantage of providing a decentralised power source which could be used in tandem with other small-scale generators such as windmills, Hayes notes, suggesting that photovoltaics "may offer the most exciting solar electric prospect".

Unfortunately, however, they also have a major disadvantage: their cost is at present prohibitive. Nevertheless, Hayes is optimistic. He notes in his study that the cost of phatovoltaic cells has dropped from $\$ 200,000$ per peak kilowatt in 1959 to about $\$ 13,000$ today. If the trend continues, and if it is helped by economies of scale, Hayes reckons that the cost may drop to as send inspectors into laboratories the ensure that the regulations are being followed and violations could result in a fine of $\$ 5,000$ per day. Particularly serious and wilful flouting of the rules could also result in a prison term, the bill states.

As for the provision allowing state and local governments to set stricter controls than the federal regulations, many scientists are now supporting federal legislation on the grounds that uniform national regulations would be preferable to a patchwork of local controls of varying stringency. The draft version of the Administration's bill would have accomplished that by simply making the federal controls paramount, but the final version would allow the states to add extra controls if they want to. According to Administration sources, the provision was changed so as not to throttle local debate over recombinant DNA but it also bows to the political reality that a move to pre-empt state and local control would be unlikely to be passed by Congress.

The focus of legislative activity has now shifted to Senator Kennedy's Health subcommittee, which held a public hearing last week. One provision which Kennedy may add to the bill is a requirement that the National Commission for the Protection of Human Subjects of Biomedical and Behavioural Research, which has been looking into a variety of biomedical issues for the past two years, be given the task of examining the long-term implications of genetic engineering.

Colin Norman

low as $\$ 500$ per kilowatt by 1985 .

If the transition to a solar era is not made during the next 50 years, Hayes argues, "the roadblocks will have been political, not technical". With massive investments already made in coal and nuclear technologies, and a large gap between future energy supply and demand generally perceived by energy planners, the political roadblocks are formidable, however. President Carter's forthcoming energy policy, which is expected to be announced next week, is likely to provide a boost to both coal and light water reactors, though it is likely to pour some cold water on longer term nuclear plans. As for solar technologies and other renewable resources, it is expected to provide nothing of the support, and certainly nothing of the magnitude which Hayes calls for. 